\title{
The vegetation and wildlife habitats of the Savuti-Mababe-Linyanti ecosystem, northern Botswana
}

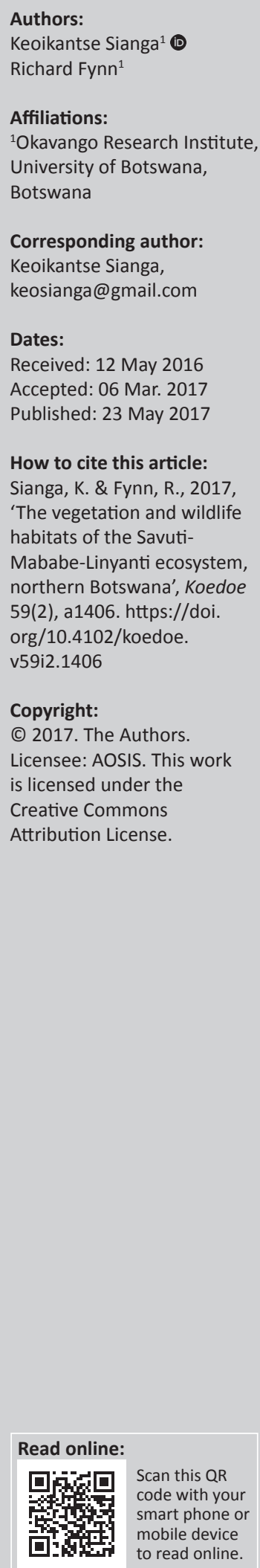

This study classified the vegetation of the Savuti-Mababe-Linyanti ecosystem (SMLE), northern Botswana and developed a detailed map that provides a reliable habitat template of the SMLE for future wildlife habitat use studies. The major vegetation units of the SMLE were determined from satellite imagery and field visits and then mapped using Landsat 8 and RapidEye imagery and maximum likelihood classifier. These units were sampled using $40 \mathrm{~m} \mathrm{x}$ $20 \mathrm{~m}\left(800 \mathrm{~m}^{2}\right)$ plots in which the coverage of all plant species was estimated. Non-metric multidimensional scaling (NMS) demonstrated that plant communities were determined by gradients in soil texture or fertility and wetness. NMS 1 represented a gradient of soil texture with seven woodland communities on sandy soils (sandveld communities and Baikiaea forest) dominated by Baikiaea plurijuga in Baikiaea forest and Terminalia sericea and Philenoptera nelsii in sandveld, with various indicator species differentiating the various sandveld community types. Mopane woodland further from and riparian woodland adjacent to permanent water was common on less sandy alluvial soils. Mineral-rich, heavy clay soils in the sump of a large paleolake system support open grassland and mixed Senegalia/Vachellia (Acacia) savanna, with the mineral-rich soils supporting grasses high in minerals such as phosphorus, calcium, sodium and potassium, and thus this region is a critical wet season range for migratory zebra. Taller, high-quality grasses in the mosaic of sandveld and mopane woodland communities provide critical grazing for taller grass grazers such as buffalo, roan and sable antelope, whereas wetland communities provide reliable green forage during the dry season for a variety of herbivores, including elephant. This study has demonstrated how large-scale environmental gradients determine functional habitat heterogeneity for wildlife.

Conservation implications: Our study demonstrated that the functionality of protected areas is determined by large-scale environmental gradients. Thus conservation science must aim to ensure that protected areas cover the full range of key environmental gradients in a region (soil texture and wetness in our study). Our habitat map provides a data base for wildlife habitat use studies in the region.

\section{Introduction}

There is growing recognition of the importance of spatial heterogeneity in determining biodiversity (MacFayden et al. 2016) and adaptive foraging options for herbivores (Hobbs et al. 2008; Hopcraft, Olff \& Sinclair 2010; Owen-Smith 2004) and predators (Hopcraft, Sinclair \& Packer 2005) and for facilitating predation avoidance and avoidance of competition among guilds of herbivores or carnivores (Mills \& Gorman 1997; Rettie \& Messier 2000). Spatial heterogeneity is strongly associated with vegetation heterogeneity, and detailed vegetation maps derived from remotesensed spectral variation are likely to represent a large proportion of spatial heterogeneity (MacFayden et al. 2016). Plant community variation on environmental gradients is associated with complex combinations of environmental factors and associated plant species composition, richness and physiognomy, leading to distinct habitat attributes for animals such as seasonal resources, predation avoidance and shelter (Fynn, Chase \& Roder 2014; Hopcraft et al. 2010). Functional differences among different plant communities in meeting the seasonally varying needs of animals have been referred to as functional habitat heterogeneity and play a key role in determining the viability of herbivore populations (Hopcraft et al. 2010; Owen-Smith 2004). Environmental factors such as soil fertility, forage quality and water availability, which covary strongly with vegetation, may also influence human settlement, crop field and livestock distribution patterns.

Development of detailed vegetation maps is, therefore, essential for (1) understanding the distribution of biodiversity across a region, (2) research on wildlife species' home range and habitat use, (3) conservation planning and (4) understanding socio-ecological interactions. 
Vegetation maps are especially useful for determining seasonal habitat use of collared wildlife species where thousands of global positioning systems (GPS) locations may be obtained from a collared animal, which cannot easily be followed up on, especially in vast wilderness regions with little road access, such as in northern Botswana. Currently, no detailed vegetation map exists for northern Botswana, with the best available product being the elephant habitat map of northern Botswana, which lacks the detail and accuracy needed for comprehensive wildlife habitat use studies (Ringrose 2006).

A key region for wildlife in northern Botswana is the regionalscale contrast of extensive floodplains of the Okavango Delta and the Linyanti Swamps, with the vast woodland systems adjacent to these wetland systems. The Savuti-MababeLinyanti ecosystem (SMLE) with its extensive wetlands and woodlands and the open grasslands of the Mababe Depression (MD) has excellent functional habitat heterogeneity for wildlife (Fynn et al. 2014), as well as great aesthetic features for tourism, providing the basis for it forming the core region for wildlife and tourism in Botswana. Thus, the SMLE is a region of key conservation importance, being one of the few remaining relatively unfragmented ecosystems in Africa with important heterogeneity of seasonal habitats that support a wide diversity of wildlife species, including important populations of rare species such as wild dog, eland, sable and roan antelope, as well as longrange migrations of several herbivore species (Fynn et al. 2014; Naidoo et al. 2014; Sianga 2014).

Thus, apart from the need for a detailed vegetation classification and habitat map for conservation planning in the SMLE and for future wildlife habitat use studies in the region, this article provides baseline ecosystem-level data on the SMLE, which allows the various herbivore and carnivore studies to be analysed in relation to the same habitat map.

The objectives of this study were to (1) classify the vegetation of the SMLE of northern Botswana, (2) develop a detailed vegetation map that provides a reliable habitat template of the SMLE for wildlife habitat use studies and for future studies and (3) discuss how the heterogeneity in vegetation and soils of the SMLE contributes to functional habitat heterogeneity for wildlife.

\section{Materials and methods Study area}

This study was done in the SMLE, northern Botswana (Figure 1), an extensive region of woodlands and open grasslands wedged between two major wetland systems the Okavango Delta and the Linyanti Swamps. The SMLE is characterised by a semi-arid climate with an annual rainfall of around $500 \mathrm{~mm}$ on the western side (Okavango Delta) and increasing eastwards to around $600 \mathrm{~mm}$ in the Chobe Enclave region (Botswana Meteorological Services). The climate is characterised by a wet season (December-April), cool, early dry season (May-August) and a hot, late dry season (September-November), where the daily maximum temperatures are regularly between $35^{\circ} \mathrm{C}$ and $40{ }^{\circ} \mathrm{C}$ during this time (September-November) (Fynn et al. 2014). Water originating from the Angolan highlands into the ecosystem through the Okavango Delta, Linyanti Swamps, Selinda Spillway and Savuti Channel leads to the development of extensive floodplain grasslands and swamps adjacent to the extensive woodland systems (Mendelsohn et al. 2010). Alluvial clays and aeolian sands in the ecosystem are occupied by Colophospermum mopane and Philenoptera nelsii-Terminalia sericea woodlands (dryland woodlands), respectively (Wolski \& Murray-Hudson 2006), and low-lying drainage systems are dominated by woodlands of mixed communities (Combretum imberbe and others) (Mendelsohn et al. 2010). A large paleolake system known as the MD (Figure 1), characterised by clays of lacustrine origin, occurs between the Okavango Delta and the Chobe region (Teter 2007). The extremely high clay soils of the MD provide key habitat heterogeneity in the general landscape of the SMLE, which is dominated by the Kalahari sands. Vegetation on the clay soils of the MD is characterised by open Senegalia/ Vachellia (Acacia) spp. savanna grasslands and higher forage quality (Fynn et al. 2014).

\section{Vegetation sampling}

Vegetation composition was sampled using $40 \mathrm{~m} \times 20 \mathrm{~m}$ $\left(800 \mathrm{~m}^{2}\right)$ plots during the wet seasons of 2014 and 2015, with sampling conducted from January to the end of March to ensure that plants had attained inflorescences for easier identification. Certain remote habitats of the MD on waterlogged heavy clay soils were inaccessible during the wet season and could only be sampled during the early dry season (April to mid-May) once the soils had dried out. Plots were stratified within homogenous vegetation units (determined visually by extensive field surveys of the region) to ensure adequate sampling of all key vegetation types within the study area (Figure 1). A total of 801 plots were located using two random numbers between 20 and 100 , with the first random number taken along an access route such as a road and the second perpendicular from the road into the plant community. Plots were generally spaced at least $500 \mathrm{~m}$ apart in each plant community. The GPS coordinates of each plot were recorded using a Garmin GPS Map 62s. All plants (trees, grasses and forbs) rooted in the plots were identified, recorded and their percentage cover estimated. Unknown plants were pressed in the field and brought to the Peter Smith Herbarium (PSUB) collection at the Okavango Research Institute (Maun, Botswana) for identification, with nomenclature for all species following The Plant List (http:/ / www.theplantlist. org). Five soil samples collected from each plot were mixed to form a composite sample, which was brought to the Okavango Research Institute laboratory for texture and nutrient analysis. 


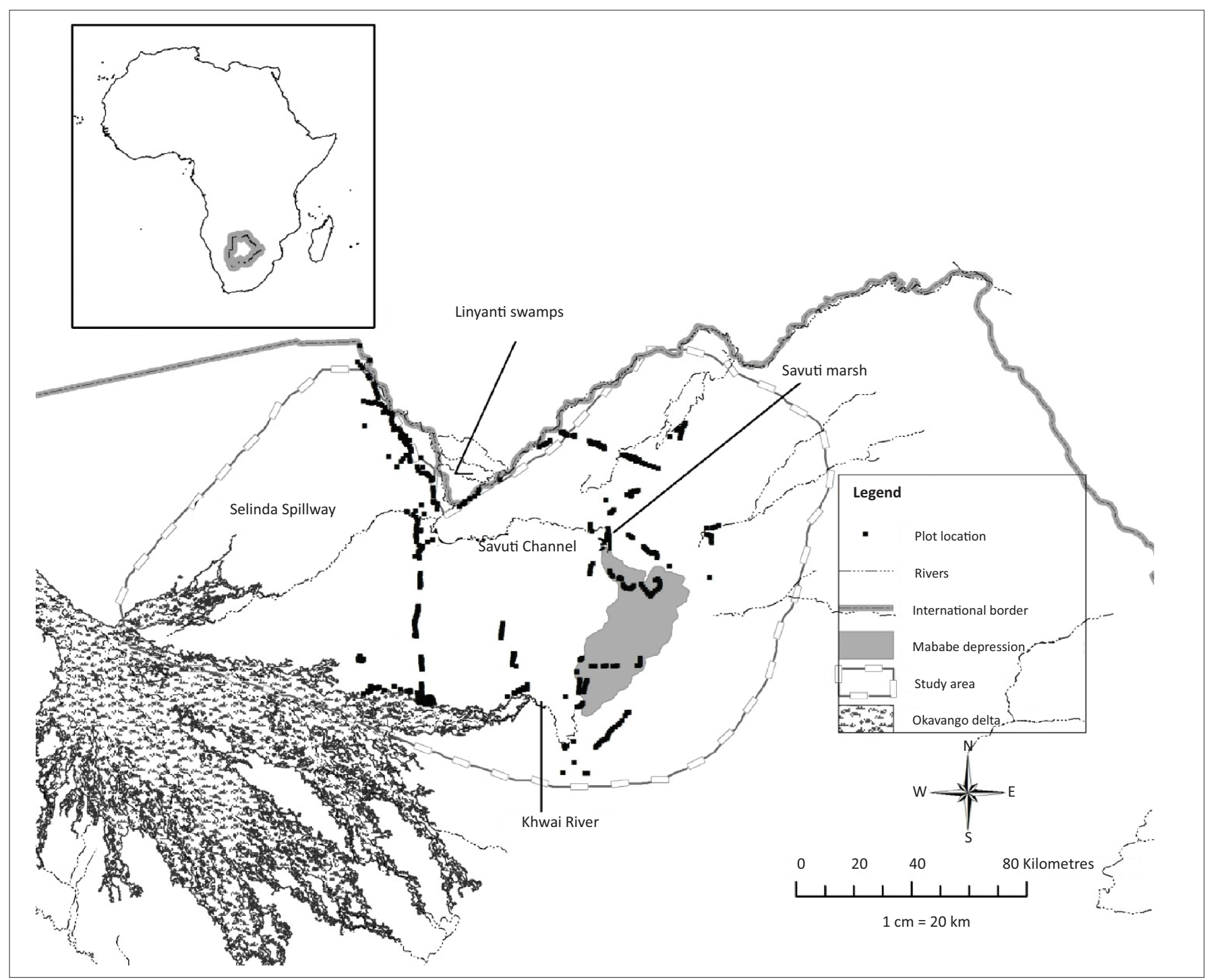

FIGURE 1: Study area depicting the Savuti-Mababe-Linyanti ecosystem and locations of sampling positions.

\section{Vegetation classification}

The data for all 801 vegetation plots (\% cover abundance of species) were standardised using relativisations by maximum in Principal Component Ordination 6 (PCORD) (McCune, Grace \& Urban 2002). These data were subjected to hierarchical cluster analysis ( $\beta$ linkage, $\beta=-0.25$, Sorensen distance) in PCORD 6 (McCune et al. 2002), comprising species (505 species) occurring at more than one site based on species distribution across 801 plots. Indicator species analysis (ISA) (Dufrene \& Legendre 1997) was used to identify levels to define ecologically meaningful communities, and indicator values (IVs) were examined for statistical significance using Monte Carlo technique in PCORD 6 (McCune et al. 2002). Differences between communities were examined using multiresponse permutation procedure (MRPP) using Sorensen distance measure (McCune et al. 2002). In addition, non-metric multidimensional scaling (NMS) was used to plot the communities in ordination space in relation to key orthogonal gradients in the vegetation data using PCORD 6 (McCune et al. 2002). Such gradients are likely related to key environmental drivers and thus provide insights into how plant communities are structured in the ecosystem.

\section{Vegetation mapping}

Owing to the vast size of the SMLE, we were unable to purchase detailed RapidEye imagery for the entire ecosystem and thus purchased RapidEye imagery to map the core area of the ecosystem, where we needed most detail for several herbivore studies currently being conducted there and then used Landsat 8 imagery to map the remainder of the ecosystem. A RapidEye composite image composed of 34 tiles and wet season Landsat Enhanced Thematic Mapper scenes from Earth Explorer USGS of the study area were radiometrically and atmospherically corrected in ENVI 4.8 (ENVI 2010). The Landsat images were mosaicked using seamless mosaic, and maximum likelihood classifier (supervised classification) in ENVI 4.8 (ENVI 2010) was used to map a subset of the 15 vegetation classes identified in the vegetation classification (reasons for mapping of a subset rather than all 15 vegetation classes is given in the results). A corrected RapidEye image was also mapped using the maximum likelihood classifier in ENVI 4.8 (ENVI 2010). The two classified images were seamlessly mosaicked together, and an area of interest was extracted by mask in 
ArcMap 10.2 (ESRI 2010). The area of each habitat was computed and converted into a minimum mapping unit in ArcMap 10.2 (ESRI 2010).

\section{Results \\ Mapping}

For mapping purposes, we required a habitat map that presented functionally distinct classes for herbivores. Thus, we grouped functionally similar classes (which, in addition, were generally difficult to distinguish from each other through remote sensing and thus difficult to map as separate communities), described by the cluster analysis (Figure 1-A1) and shown in the NMS (Figure 3). For example, the six sandveld types are not easily distinguished from each other through remote sensing and are functionally similar for herbivores, thus they can be mapped as one unit. By contrast, the communities on alluvial soils were very different functionally (e.g. wetland vs. mopane or riparian forests vs. dry floodplains) and could be easily distinguished through remote sensing and thus were mapped separately. With regard to the communities on heavy lacustrine clay soils, two distinct, functionally different communities occur, (1) the short grasslands with acacia spp. on silty soils and (2) the tall, open grasslands on vertisols, thus, functionally for herbivores, we chose to map them as two classes.

\section{Classification}

A coincident minimum of ISA $p$-value and maximum number of significant indicator species were found in seven and nine communities, respectively. Another coincident minimum of ISA $p$-value and maximum number of significant indicator species were found in 15 communities and were considered a meaningful ecological level of communities for a detailed vegetation classification. Thus, hierarchical cluster analysis done on all 801 vegetation plots recognised 15 main vegetation communities within which many sub-communities occurred (Figure 1-A1). MRPP tests of 15 communities suggested significant differences between communities ( $p<0.000$, Table 1 -A1) with chancecorrected within group agreement, $A=0.265$. Pairwise comparisons between communities suggested significant differences $(p<0.000$, Table 1-A1).

The first axis of the NMS1 analysis appears to be a gradient of soil texture and fertility, with communities on the most sandy soils having the most negative values, communities on loam soils having intermediate values and communities on extremely high clay soils having the most positive values on NMS1, respectively (Figure 3; Table 1). The second NMS axis (NMS2) appears to be a weak gradient of wetness, with communities having the most positive values on NMS2 being those that receive some sort of seasonal flooding from the annual flood pulse into the Okavango and Linyanti systems (Setaria sphacelata - Gomphocarpus fruticosus community) or seasonal rainfall (Setaria incrassataDichanthium annulatum community) or occur near permanent water with perhaps a shallow water table (Tribulus terrestris - Senna obtusifolia community) (authorities for plant species names are according to http://www. theplantlist.org).

TABLE 1: Soil texture and nutrient characteristics in the Savuti-Mababe-Linyanti ecosystem, northern Botswana.

\begin{tabular}{|c|c|c|c|c|c|c|c|c|c|}
\hline Community & $N$ & $\begin{array}{l}\text { Phosphorus } \\
\text { (Mean } \pm \text { SE) }\end{array}$ & $\begin{array}{l}\text { Potassium } \\
\text { (Mean } \pm S E)\end{array}$ & $\begin{array}{l}\text { Sodium } \\
\text { (Mean } \pm \text { SE) }\end{array}$ & $\begin{array}{c}\text { Calcium } \\
\text { (Mean } \pm \text { SE) }\end{array}$ & $\begin{array}{l}\text { Magnesium } \\
(\text { Mean } \pm \text { SE) }\end{array}$ & $\begin{array}{c}\text { Sand } \\
(\text { Mean } \pm \text { SE) }\end{array}$ & $\begin{array}{c}\text { Silt } \\
(\text { Mean } \pm \text { SE) }\end{array}$ & $\begin{array}{c}\text { Clay } \\
(\text { Mean } \pm \text { SE) }\end{array}$ \\
\hline $\begin{array}{l}\text { Baikiaea plurijuga-Baphia } \\
\text { massaiensis }\end{array}$ & 9 & $6.5 \pm 0.3$ & $412.2 \pm 69.3$ & $74.3 \pm 4.2$ & $217.5 \pm 29.7$ & $135.3 \pm 7.8$ & $96.5 \pm 0.4$ & $1.4 \pm 0.1$ & $2.1 \pm 0.2$ \\
\hline $\begin{array}{l}\text { Ipomoea chloroneura- } \\
\text { Oxygonum alatum }\end{array}$ & 16 & $5.6 \pm 0.6$ & $154.9 \pm 22.9$ & $66.0 \pm 6.7$ & $133.5 \pm 19.7$ & $121.3 \pm 2.5$ & $97.6 \pm 0.2$ & $0.9 \pm 0.1$ & $1.4 \pm 0.2$ \\
\hline $\begin{array}{l}\text { Eragrostis pallens - Ochna } \\
\text { pulchra }\end{array}$ & 14 & $6.7 \pm 1.2$ & $357.7 \pm 68.9$ & $74.2 \pm 6.2$ & $321.8 \pm 33.5$ & $130.4 \pm 10.9$ & $95.6 \pm 0.7$ & $2.3 \pm 0.5$ & $2.0 \pm 0.2$ \\
\hline $\begin{array}{l}\text { Commiphora angolensis - } \\
\text { Combretum collinum }\end{array}$ & 5 & $4.4 \pm 0.2$ & $108.9 \pm 21.9$ & $60.2 \pm 4.8$ & $156.4 \pm 20.5$ & $137.5 \pm 5.1$ & $95.3 \pm 0.4$ & $0.7 \pm 0.3$ & $0.2 \pm 0.1$ \\
\hline $\begin{array}{l}\text { Boscia albitrunca- } \\
\text { Dactyloctenium giganteum }\end{array}$ & 20 & $9.9 \pm 4.1$ & $756.6 \pm 61.7$ & $75.2 \pm 3.0$ & $380.6 \pm 56.7$ & $233.3 \pm 21.0$ & $95.1 \pm 0.4$ & $2.1 \pm 0.2$ & $2.8 \pm 0.3$ \\
\hline $\begin{array}{l}\text { Brachiaria nigropedata- } \\
\text { Combretum hereroense }\end{array}$ & 8 & $6.0 \pm 0.2$ & $856.4 \pm 38.6$ & $70.1 \pm 4.9$ & $332.3 \pm 18.3$ & $238.8 \pm 9.8$ & $93.9 \pm 0.5$ & $3.2 \pm 0.3$ & $2.8 \pm 0.2$ \\
\hline $\begin{array}{l}\text { Tribulus terrestris - Senna } \\
\text { obtusifolia }\end{array}$ & 4 & $6.8 \pm 2.4$ & $226.8 \pm 24.9$ & $82.6 \pm 5.9$ & $360.2 \pm 13.0$ & $130.5 \pm 3.9$ & $93.6 \pm 1.7$ & $3.1 \pm 1.3$ & $2.3 \pm 0.4$ \\
\hline $\begin{array}{l}\text { Colophospermum mopane - } \\
\text { Jasminum stenolobum }\end{array}$ & 30 & $5.1 \pm 0.3$ & $662.8 \pm 46.3$ & $90.3 \pm 4.4$ & $459.7 \pm 63.1$ & $169.6 \pm 9.7$ & $91.8 \pm 0.5$ & $4.5 \pm 0.3$ & $3.7 \pm 0.3$ \\
\hline $\begin{array}{l}\text { Setaria sphacelata- } \\
\text { Gomphocarpus fruticosus }\end{array}$ & 4 & $17.7 \pm 4.7$ & $2715.8 \pm 1322.3$ & $134.1 \pm 24.4$ & $5981.0 \pm 3017.5$ & $716.3 \pm 260.7$ & $68.7 \pm 15.2$ & $11.9 \pm 5.5$ & $19.3 \pm 9.7$ \\
\hline $\begin{array}{l}\text { Justicea divaricata- } \\
\text { Eragrostis superba }\end{array}$ & 26 & $10.0 \pm 1.8$ & $396.1 \pm 58.1$ & $93.7 \pm 13.6$ & $875.6 \pm 357.2$ & $150.9 \pm 14.3$ & $92.7 \pm 0.9$ & $4.0 \pm 0.6$ & $3.3 \pm 0.4$ \\
\hline $\begin{array}{l}\text { Croton megalobotrys - } \\
\text { Setaria verticillata }\end{array}$ & 8 & $25.4 \pm 9.3$ & $777.9 \pm 78.1$ & $87.5 \pm 5.1$ & $1460.9 \pm 172.9$ & $191.1 \pm 20.6$ & $89.4 \pm 0.7$ & $4.0 \pm 0.4$ & $6.5 \pm 0.7$ \\
\hline $\begin{array}{l}\text { Chloris virgata-Boerhavia } \\
\text { coccinea }\end{array}$ & 16 & $18.3 \pm 3.7$ & $1683.9 \pm 205.8$ & $203.3 \pm 60.7$ & $1765.8 \pm 446.4$ & $248.2 \pm 63.2$ & $79.8 \pm 2.9$ & $11.8 \pm 1.6$ & $8.4 \pm 1.5$ \\
\hline $\begin{array}{l}\text { Cenchrus ciliaris - Senegalia } \\
\text { mellifera }\end{array}$ & 10 & $11.9 \pm 3.7$ & $4750.5 \pm 378.6$ & $206.7 \pm 7.5$ & $6018.2 \pm 331.2$ & $329.3 \pm 19.4$ & $25.2 \pm 6.5$ & $44.2 \pm 4.1$ & $30.5 \pm 3.7$ \\
\hline $\begin{array}{l}\text { Bothriochloa insculpta } \\
\text { - Rhynchosia minima }\end{array}$ & 8 & $11.7 \pm 2.0$ & $9819.7 \pm 191.5$ & $176.5 \pm 7.5$ & $5842.1 \pm 244.5$ & $488.9 \pm 46.7$ & $9.1 \pm 1.1$ & $48.4 \pm 1.4$ & $42.5 \pm 1.1$ \\
\hline $\begin{array}{l}\text { Setaria incrassata- } \\
\text { Dichanthium annulatum }\end{array}$ & 5 & $8.5 \pm 0.9$ & $3862.4 \pm 1294.1$ & $101.1 \pm 32.8$ & $5892.7 \pm 2211.5$ & $729.3 \pm 260.8$ & $61.3 \pm 12.5$ & $19.6 \pm 5.9$ & $19.1 \pm 6.6$ \\
\hline
\end{tabular}




\section{Vegetation on Kalahari sands}

The NMS (Figure 3) delineated several vegetation communities in the SMLE that occur on deep Kalahari sands, and they appear to be differentiated according to subtle variation in the silt and clay content of the soil (Table 1). In the vegetation or habitat map, we refer to these communities on deep sands as sandveld communities (Figure 2). Although Baikiaea plurijuga - Baphia massaiensis is also found on deep sands (Table 1), we refer to it in the map as Baikiaea forest, not as sandveld (Figure 2).

\section{Baikiaea plurijuga - Baphia massaiensis}

This community is associated with high sand and low clay content of the soil (Table 1). The community is extensive and occurs from northern edge of the beachhead of the MD near Ghoha hills and extends east all the way north-east into Zimbabwe (Figure 2). It is also found in small patches near the eastern edge of the Okavango Delta from the Tsum Tsum floodplains to the Vumbura-Motswiri region and in the woodlands west of the Kwando system (Figure 2). Indicator species include Baikiaea plurijuga, Baphia massaiensis, Croton gratissimus, Hibiscus lobatum, Panicum maximum, Thunbergia reticulata and Combretum apiculatum (Table 2). Baikiaea forests, while not supporting a high density of herbivores, are critical habitats for rare herbivores such as roan and sable antelope, and thus play a key role in the functional heterogeneity of the region.

Apart from the Baikiaea forest on deep sands, there are six communities which we have collectively mapped as sandveld (Figure 2), and these are discussed below (in order of increasing NMS axis 1 value).

\section{Ipomoea chloroneura - Oxygonum alatum}

This is one of the most extensive communities occurring on deep sands, where aeolian sands have infilled ancient river channels among the alluvial soils (supporting mopane), in the extensive woodlands between the Okavango Delta and the Linyanti Swamps (Figure 2). This community is associated with soils among the highest sand and lowest silt and clay contents, as well as the lowest phosphorus, potassium, sodium and magnesium contents (Table 1), and is recognised by the dominance of Terminalia sericea in the woody layer. It is one of the most important wet season habitats for several tall grass grazers because of the abundance of high-quality tall grasses such as Digitaria eriantha. Indicator species in this community are Ipomoea chloroneura, Oxygonum alatum, Hibiscus mastersianus, Chamaecrista stricta, Erlangea misera, Chamaecrista absus, Ceratotheca sesmoides, Philenoptera nelsii, Pavonia senegalensis and Basananthe pedata (Table 2).

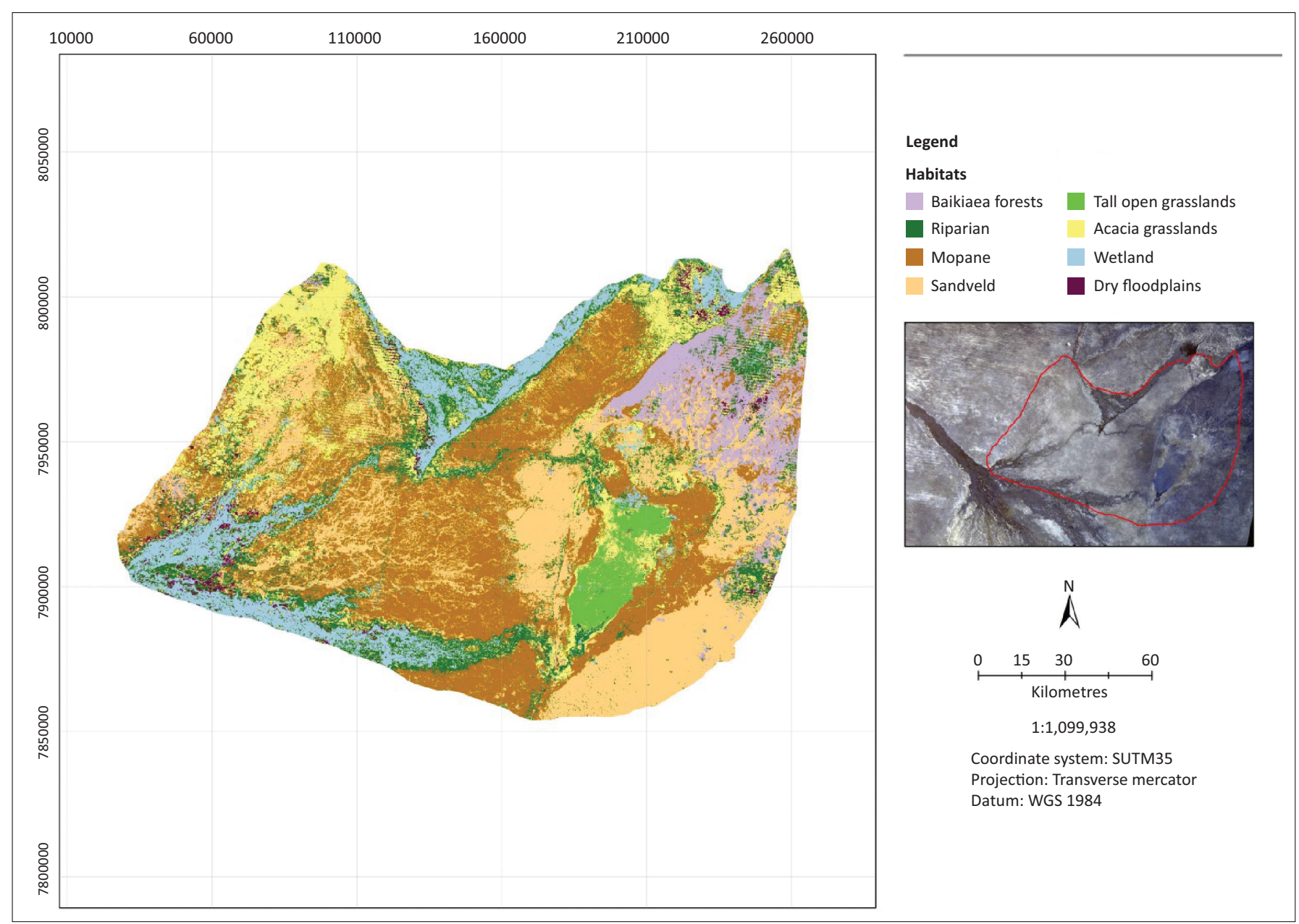

FIGURE 2: Map of Savuti-Mababe-Linyanti ecosystem Vegetation (northern Botswana). 
TABLE 2: Indicator species characteristics for 15 class divisions of plant communities in the Savuti-Mababe-Linyanti ecosystem (northern Botswana).

\begin{tabular}{|c|c|c|}
\hline Indicator species & Indicator values & $P$ \\
\hline \multicolumn{3}{|c|}{ Baikiaea plurijuga-Baphia massaiensis } \\
\hline Baikiaea plurijuga & 98.7 & 0.0002 \\
\hline Baphia massaiensis & 70.2 & 0.0002 \\
\hline Croton gratissimus & 65.9 & 0.0002 \\
\hline Hibiscus lobatum & 48.8 & 0.0002 \\
\hline Panicum maximum & 39.7 & 0.0002 \\
\hline Thunbergia reticulata & 38.6 & 0.0006 \\
\hline Combretum apiculatum & 34.2 & 0.0002 \\
\hline Vigna stenophylla & 22.5 & 0.0018 \\
\hline Dipcadi marlothii & 22.2 & 0.0016 \\
\hline Citrullus lanatus & 20.8 & 0.0010 \\
\hline Cyperus margaritaceus & 14.9 & 0.0114 \\
\hline Merremia pinnata & 11.5 & 0.0292 \\
\hline Ledebouria revoluta & 10.3 & 0.0330 \\
\hline \multicolumn{3}{|c|}{ Ipomoea chloroneura-Oxygonum alatum } \\
\hline Ipomoea chloroneura & 66.5 & 0.0002 \\
\hline Oxygonum alatum & 66.0 & 0.0002 \\
\hline Hibiscus mastersianus & 55.8 & 0.0002 \\
\hline Charmocresta stricta & 55.24 & 0.0002 \\
\hline Erlangea misera & 54.4 & 0.0002 \\
\hline Pavania senegalensis & 45.4 & 0.0002 \\
\hline Charmocresta absus & 32.4 & 0.0002 \\
\hline Ceratotheca sesmoides & 25.2 & 0.0012 \\
\hline Basananthe pedata & 21.4 & 0.0012 \\
\hline Philenoptera nelsii & 20.4 & 0.0038 \\
\hline \multicolumn{3}{|c|}{ Eragrostis pallens - Ochna pulchra } \\
\hline Eragrostis pallens & 50.0 & 0.0002 \\
\hline Ochna pulchra & 41.2 & 0.0002 \\
\hline Burkea africana & 31.2 & 0.0002 \\
\hline Aristida stipitata & 32.0 & 0.0002 \\
\hline Phyllanthus burchellii & 32.8 & 0.0008 \\
\hline Phyllanthus mendesii & 29.6 & 0.0012 \\
\hline Digitaria eriantha & 18.1 & 0.0028 \\
\hline Dicoma schinzii & 18.1 & 0.0056 \\
\hline Euphorbia crotonoides & 11.1 & 0.0504 \\
\hline \multicolumn{3}{|c|}{ Commiphora angolensis - Combretum collinum } \\
\hline Commiphora angolensis & 94.6 & 0.0002 \\
\hline Combretum collinum & 80.8 & 0.0002 \\
\hline Senegalia ataxacantha & 76.1 & 0.0002 \\
\hline Combretum molle & 73.7 & 0.0002 \\
\hline Evolvulus alsinoides & 73.4 & 0.0002 \\
\hline Neorautanenia amboensis & 73.3 & 0.0002 \\
\hline Xenostegia tridentata & 72.1 & 0.0002 \\
\hline Waltheria indica & 68.7 & 0.0002 \\
\hline Ochna serrulata & 65.4 & 0.0002 \\
\hline Bauhinia petersiana & 52.0 & 0.0002 \\
\hline Duosperma crenatum & 48.8 & 0.0002 \\
\hline Acanthosicyos naudinianus & 45.4 & 0.0002 \\
\hline Commiphora africana & 42.6 & 0.0004 \\
\hline \multicolumn{3}{|c|}{ Boscia albitrunca - Dactyloctenium giganteum } \\
\hline Boscia albitrunca & 44.0 & 0.0002 \\
\hline Dactyloctenium giganteum & 35.6 & 0.0004 \\
\hline Indigofera flavicans & 33.0 & 0.0016 \\
\hline Sida chrysantha & 27.4 & 0.0010 \\
\hline Mundulea sericea & 21.3 & 0.0036 \\
\hline Ocimum gratissimum & 20.0 & 0.0122 \\
\hline Digitaria ternata & 15.5 & 0.0058 \\
\hline Cleome hirta & 12.5 & 0.0442 \\
\hline \multicolumn{3}{|c|}{ Brachiaria nigropedata-Combretum hereroense } \\
\hline Brachiaria nigropedata & 85.6 & 0.0002 \\
\hline Combretum hereroense & 68.0 & 0.0002 \\
\hline
\end{tabular}

TABLE 2 (Continues...): Indicator species characteristics for 15 class divisions of plant communities in the Savuti-Mababe-Linyanti ecosystem (northern Botswana). Indicator species In
Brachiaria nigropedata-Combretum hereroense
Lantana angolensis

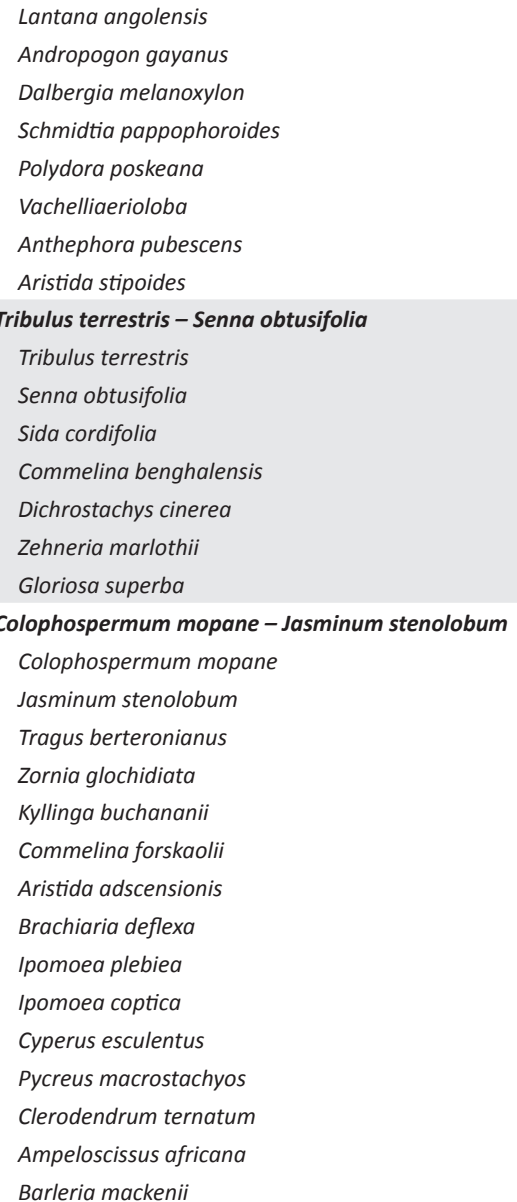
ndicator values

$\boldsymbol{P}$

$\begin{array}{ll}65.0 & 0.0002 \\ 63.2 & 0.0002 \\ 55.8 & 0.0002 \\ 46.5 & 0.0002 \\ 33.9 & 0.0008 \\ 32.7 & 0.0014 \\ 31.2 & 0.0006 \\ 24.8 & 0.0014\end{array}$

$70.5 \quad 0.0002$

$36.7 \quad 0.0002$

$33.8 \quad 0.0002$

$23.0 \quad 0.0028$

$22.5 \quad 0.0158$

$17.1 \quad 0.0122$

$15.9 \quad 0.0186$

$76.0 \quad 0.0002$

$54.6 \quad 0.0002$

$50.2 \quad 0.0004$

$46.4 \quad 0.0002$

$43.5 \quad 0.0002$

$41.7 \quad 0.0006$

$36.9 \quad 0.0002$

$36.0 \quad 0.0004$

$30.3 \quad 0.0018$

$27.8 \quad 0.0034$

$24.0 \quad 0.0076$

$21.6 \quad 0.0062$

$18.3 \quad 0.0152$

$12.8-0.0158$

$12.3 \quad 0.0260$

Setaria sphacelata-Gomphocarpus fruticosus

Setaria sphacelata

Gomphocarpus fruticosus

$99.0 \quad 0.0002$

Cyperus longus

Crotalaria platysepala

Momordica balsamina

Sesamum triphyllum

Bulbostylis hispidula

Cymbopogon caesius

Limeum viscosum

Melinis repens

Acrotome inflata

Urochloa trichopus

$96.2 \quad 0.0002$

$89.2 \quad 0.0002$

$83.0 \quad 0.0002$

$80.5 \quad 0.0002$

$67.8 \quad 0.0002$

$66.1 \quad 0.0002$

$56.0 \quad 0.0002$

$49.0 \quad 0.0010$

$30.4 \quad 0.0018$

$28.6 \quad 0.0018$

$24.4 \quad 0.0004$

Justicea divaricata - Eragrostis superba

Justicea divaricata

Eragrostis superba

$21.1 \quad 0.0050$

Eragrostis trichophora

0.0186

Geigeria schinzii

Orthanthera jasminiflora

$14.7 \quad 0.0128$

$13.9 \quad 0.0116$

$13.0 \quad 0.0408$

$\begin{array}{lll}\text { Justicia betonica } & 12.7 & 0.0240\end{array}$

Imperata cylindrica

Polygonum decipiens

$11.7 \quad 0.0274$

$11.7 \quad 0.0158$

Croton megalobotrys - Setaria verticillata

Croton megalobotrys

0.0002

Setaria verticillata

Diospyros mespiliformis

0002

Philenoptera violacea

0.0002

Senegalia nigrescens 0.0002 
TABLE 2 (Continues...): Indicator species characteristics for 15 class divisions of plant communities in the Savuti-Mababe-Linyanti ecosystem (northern Botswana).

\begin{tabular}{|c|c|c|}
\hline Indicator species & Indicator values & $P$ \\
\hline \multicolumn{3}{|c|}{ Croton megalobotrys - Setaria verticillatat } \\
\hline Asystasia gangetica & 54.8 & 0.0002 \\
\hline Astripomoea lachnosperma & 49.2 & 0.0002 \\
\hline Blainvillea acmella & 44.4 & 0.0002 \\
\hline Berchemia discolor & 43.7 & 0.0002 \\
\hline Acalypha indica & 42.5 & 0.0002 \\
\hline Combretum mossambicense & 39.4 & 0.0004 \\
\hline Cocculus hirsutus & 37.7 & 0.0004 \\
\hline Hibiscus ovalifolius & 37.5 & 0.0004 \\
\hline Blepharis Maderaspatensis & 35.9 & 0.0004 \\
\hline \multicolumn{3}{|c|}{ Chloris virgata - Boerhavia coccinea } \\
\hline Chloris virgata & 74.8 & 0.0002 \\
\hline Boerhavia coccinea & 52.3 & 0.0002 \\
\hline Vachellia tortilis & 33.7 & 0.0006 \\
\hline Hermannia kirkii & 31.8 & 0.0008 \\
\hline Vachellia hebeclada & 29.4 & 0.0010 \\
\hline Cucumis anguria & 28.2 & 0.0004 \\
\hline Dicoma tomentosa & 26.7 & 0.0046 \\
\hline Aerva leucura & 26.4 & 0.0010 \\
\hline \multicolumn{3}{|c|}{ Cenchrus ciliaris - Senegalia mellifera } \\
\hline Cenchrus ciliaris & 76.5 & 0.0002 \\
\hline Senegalia mellifera & 67.9 & 0.0002 \\
\hline Indigofera scaberrima & 20.8 & 0.0020 \\
\hline Euphorbia polycephala & 20.1 & 0.0022 \\
\hline \multicolumn{3}{|c|}{ Bothriochloa insculpta - Rhynchosia minima } \\
\hline Bothriochloa insculpta & 57.6 & 0.0002 \\
\hline Rhynchosia minima & 39.4 & 0.0004 \\
\hline Cyathula orthacantha & 34.0 & 0.0004 \\
\hline Leonotis nepetifolia & 32.2 & 0.0004 \\
\hline Dinebra retroflexa & 30.6 & 0.0002 \\
\hline \multicolumn{3}{|c|}{ Setaria incrassata - Dichanthium annulatum } \\
\hline Setaria incrassata & 99.9 & 0.0002 \\
\hline Dichanthium annulatum & 92.3 & 0.0002 \\
\hline Enicostema axillare & 70.3 & 0.0002 \\
\hline Panicum coloratum & 63.2 & 0.0002 \\
\hline Cynodon dactylon & 53.8 & 0.0002 \\
\hline Digitaria milanjiana & 34.5 & 0.0006 \\
\hline Aristida scrabrivalvis & 28.5 & 0.0006 \\
\hline Indigofera schimperi & 28.4 & 0.0004 \\
\hline Aristida hordeacea & 20.1 & 0.0028 \\
\hline Bracharia eruciformis & 15.4 & 0.0066 \\
\hline Brachiaria retiforms & 14.9 & 0.0054 \\
\hline
\end{tabular}

$\dagger$, Data continues from previous page.

\section{Eragrostis pallens - Ochna pulchra}

Similar to the Ipomoea chloroneura - Oxygonum alatum community, the Eragrostis pallens - Ochna pulchra community is associated with soils among the highest sand content and lowest phosphorus, potassium, sodium and magnesium contents (Table 1). Like the previous community, it is recognised by the dominance of $T$. sericea in the woody layer; however, Eragrostis pallens, Ochna pulchra, Burkea africana, Aristida stipitata, Phyllanthus burchellii, D. eriantha, Dicoma schinzii, Euphorbia critonoides and Phyllanthus mendesii are some of the characteristic species which separate it from the previous community (Table 2).

\section{Commiphora angolensis - Combretum collinum}

This community is spatially separated from other sandveld communities, being found only south-east of the MD and appears to be an extensive Kalahari community, extending towards Nxai Pan and the Central Kalahari Game Reserve (Figure 2). It is associated with soils of the lowest clay contents and highest sand contents, as well as the lowest phosphorus, potassium, sodium and magnesium contents (Table 1), and and is characterised by woody species not seen in typical sandveld communities west of the MD, such as Commiphora angolensis, Combretum collinum and Senegalia (Acacia) ataxacantha. This community's position in the NMS (Figure 3), however, suggests that its plant composition is more similar to the communities with soils of intermediate clay content, and therefore, we suspect that either there is more clay in the subsoil (we only sampled the topsoil) or the sands are not as deep as in the previous two communities. The structure is also different from the other sandveld types, which are relatively tall woodlands, whereas Commiphora angolensis Combretum collinum sandveld is more of a shrubland, which may also suggest that the soils are not as deep. Indicator species include C. angolensis, C. collinum, S. ataxacantha, Combretum molle, Evolvulus alsinoides, Neorautanenia amboensis, Xenostegia tridentata, Waltheria indica, Ochna serrulata, Bauhinia petersiana, Duosperma crenatum, Acanthosicyos naudinianus and Commiphora africana (Table 2). It serves as a key wet season habitat for tall grass grazers such as buffalo, eland and roan antelope, probably because it occurs far from any permanent water sources (Figure 2) and, therefore, has among the highest cover of the high-quality grass $D$. eriantha.

\section{Boscia albitrunca - Dactyloctenium giganteum}

This community, although still a sandveld community on sandy soils, was associated with higher clay and calcium and phosphorus contents than other sandveld types (similar to Brachiaria nigropedata - Combretum hereroense community in clay content) (Table 1). It is mainly found around the peripheries of Paleolake Mababe (MD) (Figure 2), where there was some moderate deposition of clay and silt by the paleolake waters. Indicator species are Boscia albitrunca, Dactyloctenium giganteum, Indigofera flavicans, Sida chrysantha, Mundulea sericea, Ocimum gratissimum, Digitaria ternata and Cleome hirta (Table 2). There is an abundance of the high-quality grazing grass $D$. giganteum which, together with the important browse provided by $B$. albitrunca, results in this community type being a key wet season habitat for herbivores such as buffalo and a dry season habitat for eland and other browsers in the SMLE.

\section{Brachiaria nigropedata - Combretum hereroense}

The Brachiaria nigropedata-Combretum hereroense community, similar to the Boscia albitrunca - Dactyloctenium giganteum community, was associated with some moderate degree of ancient sediment deposition in the peripheries of Paleolake Mababe and around the Kwando-Linyanti system, resulting in more clay than in the other sandveld community types (Table 1). It serves as a key wet season habitat for buffalo because of an abundance of one of their most favoured grasses, B. nigropedata. Indicator species include B. nigropedata, C. hereroense, Lantana angolensis, Andropogon 
gayanus, Dalbergia melanoxylon, Schmidtia pappophoroides and Polydora poskeana (Table 2).

\section{Tribulus terrestris - Senna obtusifolia}

The Tribulus terrestris - Senna obtusifolia community occurs on deep sands but always adjacent to riparian vegetation (Croton megalobotrys - Setaria verticillata and Justicea divaricata Eragrostis superba communities), found near water bodies of the Okavango Delta, Linyanti Swamps, Selinda Spillway and the Savuti Channel. Although the sands of this community are deep, they have higher clay content (Table 1), which again is likely associated with ancient sediment deposition from previous water bodies or extreme floods. This community is recognised by the dominance of the woody layer by tall P. nelsii (Kalahari appleleaf) and with very little T. sericea occurrence (as opposed to other sandveld communities where T. sericea is common), which is likely because of the higher clay content in these sandy soils. Indicator species included T. terrestris, S. obtusifolia, Sida cordifolia, Dichrostachys cinerea and Zehneria marlothii (Table 2).

\section{Vegetation on alluvial loam soils}

These communities occur at intermediate levels of silt and clay (as compared with the lower levels of silt and clay of the sandveld communities) as a result of ancient alluvial deposition of sediments.

\section{Colophospermum mopane - Jasminum stenolobum}

This community is recognised by the dominance of the woody layer by C. mopane, which appears to dominate once the clay content of the soil reaches a critical level but not too high where other communities exist (Table 1). This is an extensive community that occurs all over the ecosystem, near and further from permanent water (Figure 2). Seasonal waterholes occur in this community and serve as drinking points for various herbivores during the wet season and grasses, while sparse, are often palatable. Indicator species in mopane woodland include C. mopane, J. stenolobum, Tragus berteronianus, Zornia glochidiata, Kyllinga buchananii, Brachiaria deflexa and Aristida adscensionis (Table 2).

\section{Setaria sphacelata - Gomphocarpus fruticosus}

This community was associated with high silt-clay and intermediate sand contents of the soil (Table 1), but the key feature driving species composition is that it is seasonally inundated by floodwaters from the major wetland systems of the region. The community is common in moderately-flooded zones within the overall wetland system shown in the map (Figure 2). However, our focus was on the dryland communities, and our sampling regime in wetlands was limited and not designed to capture the variation in wetland community composition on flooding depth and duration gradients; hence, this community represents one of many different wetland community types. Characteristic species of this community type included Setaria sphacelata, Gomphocarpus fruticosus, Cyperus longus, Crotalaria platysepala, Momordica balsamina, Sesamum triphyllum and Bulbostylis hispidula (Table 2). Wetlands provide critical dry season grazing for herbivores because of their shallow water tables and the ability to provide green forage for herbivores during the dry season.

\section{Justicea divaricata - Eragrostis superba}

This is an open grassland community found directly adjacent to floodplains (mapped as dry floodplains in the map) along the major water bodies (Figure 2) and is associated with moderate silt-clay, and by intermediate sand, phosphorus, potassium and calcium contents of the soil (Table 1). Although this community is rarely (if ever) subject to flooding, it is probably maintained in a treeless state by high water tables from the adjacent floodplains. Indicator species include Justicea divaricata, Eragrostis superba, Eragrostis trichophora, Geigeria schinzii, Orthanthera jasminiflora and Justicia betonica (Table 2).

\section{Croton megalobotrys - Setaria verticillata}

This is a riparian woodland community (Figure 2), associated with major water bodies in the region (Table 1). Species including Croton megalobotrys, Setaria verticillata, Diospyros mespiliformis, Philenoptera violacea, Senegalia (Acacia) nigrescens and Asystasia gangetica characterised this community (Table 2). Riparian woodlands can occur as open or closed woodlands. Open riparian woodlands are structurally characterised by open canopy woodlands dominated by $P$. violacea, S. nigrescens and C. imberbe, whereas closed riparian woodlands are characterised by tall, closed canopy woodlands dominated by C. megalobotrys, D. mespiliformis, P. violacea, S. nigrescens and C. imberbe. In the map, these two riparian woodland communities were mapped as riparian woodlands (Figure 2).

\section{Vegetation on heavy clay lacustrine deposits of the sump of the Mababe Depression}

\section{Chloris virgata - Boerhavia coccinea}

The Chloris virgata - Boerhavia coccinea community occurs on the more silty, intermediate clay soils on the edge of the sump of the MD (as well as in areas adjacent to the Linyanti Swamps and Kwando River) and was associated with high silt, phosphorus and calcium (Table 1). It is included under Acacia grasslands in the vegetation map (Figure 2), named as such because these communities are characterised by short grasslands with acacia species in the woody layer (of varying tree density). This is a widespread community that develops where the clay content reaches higher levels than that found in alluvial soils. Thus, this community type is associated with water bodies that could have deposited those clays such as the Paleolake Mababe or the Kwando/ Linyanti Swamps (Figure 2). This community was characterised by Chloris virgata, Boerhavia coccinea, Vachellia (Acacia) tortilis, Hermannia kirkii, Vachellia (Acacia) hebeclada, Cucumis anguria, Dicoma tomentosa and Aerva leucura (Table 2). The community is dominated by the highly palatable annual grasses, C. virgata and Urochloa trichopus, and forms a critical wet season grazing resource on the edge of the sump of the 
MD for migratory zebra, as well as for tsessebe, impala and wildebeest. One of the key functional features of this community for herbivores is that it offers the highest phosphorus levels in soils and grasses of all community types in the ecosystem (Table 1 ).

As one moves off the silty soils on the edge of the sump of the MD, which support the Chloris virgata - Boerhavia coccinea community, towards the centre of the MD, soils become deep, heavy black vertisols dominated by taller grasses such as Cenchrus ciliaris and Bothriochloa insculpta. The vegetation on these vertisols is mapped as tall, open grasslands (Figure 2) and consists of two main communities, (1) the Cenchrus ciliaris - Senegalia (Acacia) mellifera community and (2) the Bothriochloa insculpta - Rhynchosia minima community.

\section{Cenchrus ciliaris - Senegalia mellifera}

This open savanna grassland community occurs on deep black clay soils (vertisols) deeper into the MD and was associated with soils among the lowest sand content and highest silt-clay content and importantly had by far the highest soil calcium and potassium content in the SMLE (Table 1). Indicator species are C. ciliaris, S. mellifera, Indigofera scaberrima and Euphorbia polycephala (Table 2). The very high soil fertility of the Cenchrus ciliaris - Senegalia mellifera community (Table 1) makes this habitat, together with the Chloris virgata - Boerhavia coccinea community, which are directly adjacent to each other, an extremely important wet season range for the large migratory zebra population. Thus, these two MD vegetation communities make up a critical part of the functional heterogeneity of the region.

\section{Bothriochloa insculpta - Rhynchosia minima}

This open savanna grassland community occurs on similar soils to the previous community (Table 1), but it makes up much less area on the MD. Bothriochloa insculpta, Rhynchosia minima, Cyathula orthacantha, Leonotis nepetifolia and Dinebra retroflexa characterised this community (Table 2 ). Dominance by the unpalatable $B$. insculpta makes this community type less important for wildlife.

\section{Setaria incrassata - Dichanthium annulatum}

This open grassland community also occurs on the MD, being found as vast, extremely open grasslands in the far north-eastern part of the MD, and is characterised by seasonal flooding from rainfall. Soils in this community are not as high clay as others on the MD (Table 1); however, from a structural point of view, the vegetation is mapped as tall, open grassland because it is a tall grass community although very different in composition to the other tall grass communities on the MD (Figure 2). Setaria incrassata, Dichanthium annulatum, Enicostema axillare, Panicum coloratum, Cynodon dactylon, Digitaria milanjiana and Aristida scrabrivalvis are some of the species that characterised this community (Table 2). The community appears to be utilised by many roan antelope over the dry season.

\section{Discussion}

\section{Vegetation classification and mapping of the Savuti-Mababe-Linyanti ecosystem}

The vegetation of the SMLE was clustered into 15 major vegetation communities characterised by different herbaceous and woody species (Figure 3), with the primary axis of variation in plant community composition (NMS1) appearing to be driven by variation in soil texture and fertility (Figure 3; Table 1). The secondary axis of variation in plant community composition (NMS2) appeared to be driven by wetness, although it was not a clear effect as with the texture gradient probably because we focused mainly on dryland communities. The landscape template, which provides the basis of the vegetation heterogeneity of the region, was formed by a variety of processes. The mosaic of sand-filled paleoriver channels among alluvial deposits that supports the mopane-sandveld woodland mosaic between the Okavango Delta and the Linyanti Swamps was formed by ancient wetlands similar to the current delta, with the river channels subsequently becoming infilled by Kalahari sands of aeolian origin (McCarthy, Gumbricht \& Mccarthy 2005). Similarly, the deep sands supporting the Baikiaea forests are of aeolian origin (McCarthy et al. 2005). The vast $3000 \mathrm{~km}^{2}$ MD originates from Paleolake Mababe (Teter 2007), which has a central sump of about $70 \mathrm{~km} \times 20 \mathrm{~km}$, where lacustrine clays and sediments deposited, giving rise to the deep vertisols of the MD. Between the beachhead of the lake and the sump zone is a zone of soils where it appears that deposition of lacustrine clays declined with increasing distance from the sump zone. Thus, the inner sump has soils of the highest clay content supporting the Bothriochloa insculpta - Rhynchosia minima and Cenchrus ciliaris - Senegalia mellifera communities, followed by the edges of the sump with more silty soils supporting the Chloris virgata-Boerhavia coccinea community, then a zone of silty sands supporting mopane woodland and between the mopane and the beachhead of the lake are sandy soils but with higher clay and silt than the typical aeolian sands, which support the Boscia albitrunca - Dactyloctenium giganteum and Brachiaria nigropedata - Combretum hereroense sandveld communities (Figure 2).

Outside the MD, the typical aeolian sands have the lowest clay and silt contents because they received no lacustrine sediment deposition. The extremely low clay sands support the Ipomoea chloroneura-Oxygonum alatum, Eragrostis pallens-Ochna pulchra and Commiphora angolensis - Combretum collinum sandveld communities. Species such as C. angolensis, C. collinum, B. plurijuga, B. massaiensis, P. nelsii, O. pulchra, B. africana and T. sericea which dominated communities growing on sandy soils in this study were also found as indicator species for sandy regions in other studies (Coetzee et al. 1976; Gertenbach \& Potgieter 1978; Tedder 2012; Tedder et al. 2013).

The mopane community was associated with alluvial soils of slightly higher clay than the sandveld communities (Table 1), as observed elsewhere (Tedder 2012; Tedder et al. 2013; 


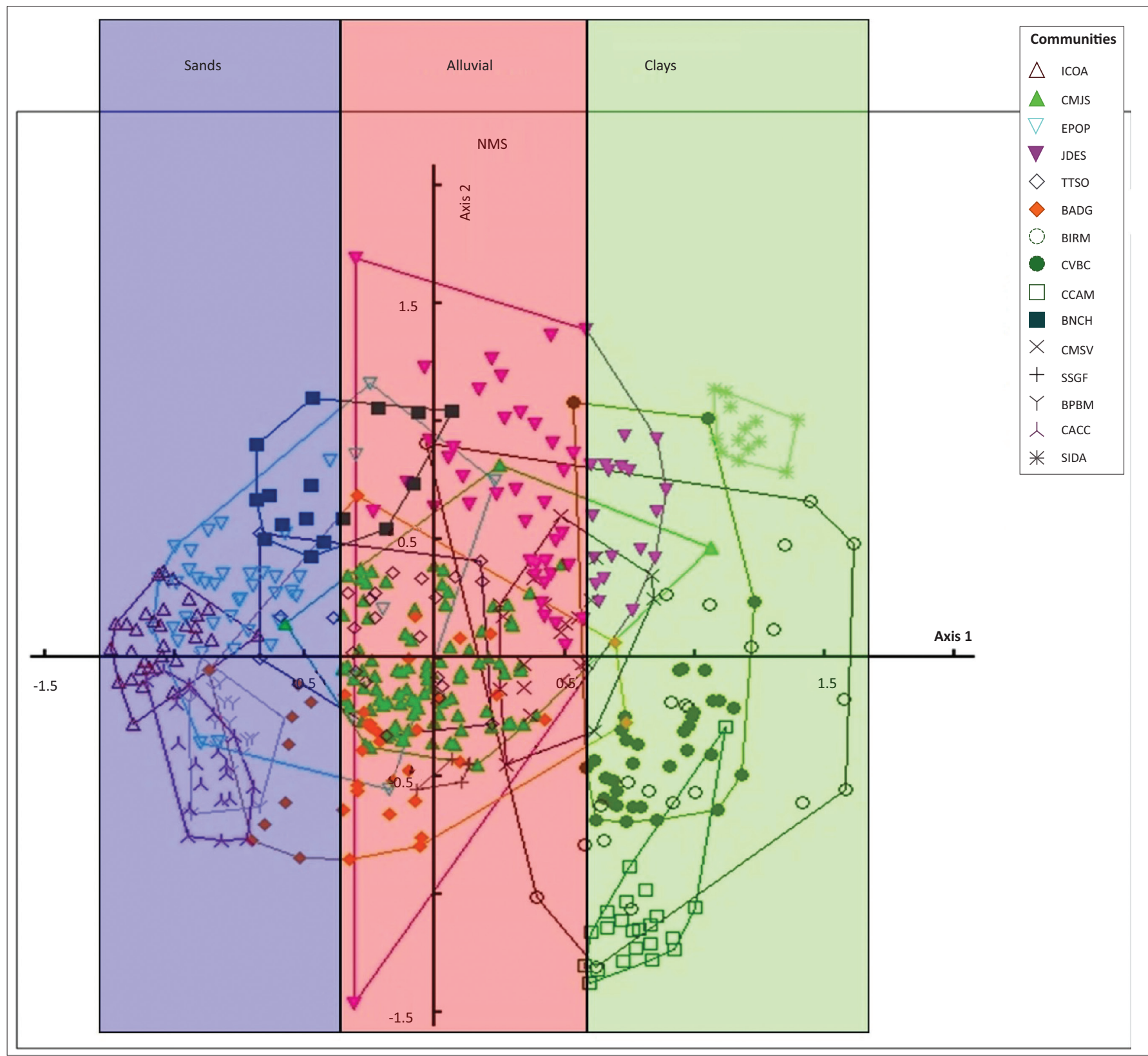

BADG, Boscia albitrunca - Dactyloctenium giganteum; BIRM, Bothriochloa insculpta - Rhynchosia minima; BNCH, Brachiaria nigropedata - Combretum hereroense; BPBM, Baikiaea plurijuga Baphia massaiensis; CACC, Commiphora angolensis - Combretum collinum; CCAM, Cenchrus ciliaris - Senegalia mellifera; CMJS, Colophospermum mopane - Jasminum stenolobum; CMSV, Croton megalobotrys - Setaria verticillata; CVBC, Chloris virgata - Boerhavia coccinea; EPOP, Eragrostis pallens - Ochna pulchra; ICOA, Ipomoea chloroneura - Oxygonum alatum; JDES, Justicea divaricata Eragrostis superba; SIDA, Setaria incrassata - Dichanthium annulatum; SSGF, Setaria sphacelata - Gomphocarpus fruticosus; TTSO, Tribulus terrestris - Senna obtusifolia.

FIGURE 3: Non-metric multidimensional scaling ordination of plant communities on 801 plots.

Van Voorthuizen 1976; Wolski \& Murray-Hudson 2006). The mopane and sandveld communities are widely distributed across the ecosystem, forming a woodland mosaic of mopane woodland on alluvial soils alternating with sandveld woodland on paleoriver channels infilled with Kalahari sands (Figure 2). The mopane-sandveld mosiac (as well as Baikiaea forest) provides key habitat for herbivore species favouring medium and tall grasses, such as buffalo, roan and sable antelope and elephant (Bennitt, Bonyongo \& Harris 2014, 2015; Fynn et al. 2014; Sianga 2014; Taolo 2003), because of the abundance of digestible, leafy forage of high-quality grass species dominant in sandveld woodland (e.g. D. eriantha, Panicum maximum and Schmidtia papophoroides), as well as D. milanjiana and Panicum maximum in mopane woodland (Sianga et al. 2017b). Importantly, these highquality grasses are most abundant far from permanent water (>15 km - $20 \mathrm{~km}$ ) (Sianga et al. 2017b), which explains why buffalo tend to favour the woodlands furthest from permanent water during the wet season (Bennitt et al. 2014; Sianga 2014; Sianga, Fynn \& Bonyongo 2017a; Sianga et al. 2017b), as do roan and sable antelope (Havemann 2014; Hensman et al. 2014). In addition, the numerous ephemeral waterholes of the mopane woodland allow herbivores to remain far out from permanent water in these woodlands during the wet season where they are able to avoid high concentrations of predators (Harrington et al. 1999). Once the waterholes dry up during the dry season, herbivores are forced to move closer to the permanent water sources of the 
Okavango Delta and Linyanti Swamps, where buffalo forage mainly in the wetlands (Bennitt et al. 2014, 2015; Sianga 2014; Sianga et al. 2017a), whereas roan and sable antelope visit the wetlands only every 3-4 days to drink and then return back to the safety of the woodlands far from water (Havemann 2014; Hensman et al. 2014). Thus, these vast woodland systems provide key functional habitat heterogeneity for provision of high-quality forage far from water during the wet season and low predation risk all year round.

The Croton megalobotrys - Setaria verticillata community, a riparian woodland (riverine) community, was correlated with silt-clay soils and occurred along edges of watercourses (Witkowski \& O'Connor 1996). This community was dominated by species such as Croton megalobotrys, P. violacea, Combretum mossambicense, D. mespiliformis and S. nigrescens, which are adapted to obtaining soil moisture through lateral ground-water discharge from higher water tables (Ellery, Ellery \& Mccarthy 1993; Hamandawana 2011; Ringrose et al. 2007). The Setaria sphacelata - Gomphocarpus fruticosus community, a floodplain grassland type found along watercourses, had grass (S. sphacelata) and sedge (C. longus) or forbs (G. fruticosus) as indicator species suggesting extensive wetness, as these species are mostly abundant in wetlands or swamp margins (Heath \& Heath 2009). This community probably experiences periods of dryness over the annual cycle as indicated by the presence of opportunistic dryland species (C. platysepala, M. balsamina, S. triphyllum and B. hispidula). Variation in wetland community composition is driven by gradients of flood depth and duration, with $C$. dactylon often characterising the parts of the gradient with the lowest depth and duration of flooding, Panicum repens and S. sphacelata often characterising areas with intermediate depth and duration of flooding and tall sedges and grasses such as Oryza longistaminata and Vossia cuspidata characterising areas of the gradient with the largest depth and duration of flooding (Fynn et al. 2015; MurrayHudson et al. 2011, 2014). This variation in composition and phenology on flooding gradients provides important variation in green forage supply for herbivores from the early to late dry season, owing to variation in availability of soil moisture for growth, allowing for adaptive foraging over the dry season (Fynn et al. 2015). Our sampling focused on the dryland communities, and we did not attempt to sample across the flood depth and duration gradient in the wetlands; thus, the Setaria sphacelata - Gomphocarpus fruticosus community represents only a small part of the variation in plant community composition that would occur in the region mapped as wetland in Figure 2. The spatial location of various wetland community types is not a constant and will shift location within the bounds of the area mapped as wetland (Figure 2) according to variation in flooding regimes over time. From a conservation management perspective, however, it should be recognised that the overall wetland community shown in the map (Figure 2) represents gradients of wetness and composition that provide critically important forage and adaptive foraging options for many herbivore species from the early to late dry season right across Africa (Fynn et al. 2015) and in the SMLE (Bartlam-Brooks, Bonyongo \& Harris 2013; Bennitt et al. 2014; Fynn et al. 2014; Sianga et al. 2017a). Consequently, linkages between large wetland systems and adjacent dryland systems must be maintained to ensure that functional habitat heterogeneity is maintained (Fynn et al. 2015; Hopcraft et al. 2010).

Communities on the high clay soils of the MD, especially the Chloris virgata - Boerhavia coccinea and Cenchrus ciliaris Senegalia mellifera communities, are critical wet season habitats for the large zebra migration in the region, as well as for wildebeest, tsessebe and impala (Fynn et al. 2014; JoosVandewalle 2000; Sianga 2014; Sianga et al. 2017a). This is because of the high clay soils and accumulation of a high concentration of minerals in the soil when it was a lake system (Teter 2007). The P-rich soils give rise to high P content in grass leaves (as well as other minerals) (Fynn et al. 2014; Joos-Vandewalle 2000; Sianga 2014). Thus, pregnant and lactating herbivores can obtain sufficient intake of nutrients to meet their high demands for nutrients during the wet season, a key functional aspect of wet season ranges for herbivores (Hopcraft et al. 2010; Owen-Smith 2004). In this regard, the Chloris virgata - Boerhavia coccinea community on the edge of the MD appears to be particularly important for $\mathrm{P}$, having the highest soil P levels (Table 1), while the vertisols of the Cenchrus ciliaris - Senegalia mellifera communities deeper into the MD have the highest concentrations of potassium and calcium. This may explain why zebra are observed to switch their foraging bouts between Chloris virgata - Boerhavia coccinea community and the Cenchrus ciliaris - Senegalia mellifera community over the day (Sianga 2014), which may be a mechanism to maximise overall intake of key minerals, protein and energy during the wet season (Owen-Smith 2002). Also, the open grasslands of the MD provide better visibility, which reduces predation risk and is thus suitable as a calving ground. In fact, selection for low predation-risk habitat for the calving period may dominate the hierarchy of habitat selection decisions made by ungulates (Rettie \& Messier 2000). During the day, zebra appeared to make use of short, open grasslands with high visibility (mainly the Chloris virgata - Boerhavia coccinea community) but at night, they moved further into the MD to the S. mellifera woodlands perhaps as an adaptive strategy to elude predators - reliance on sighting predators during the day and hiding from them at night (Sianga 2014).

Dominance of much of the southern half of the MD by C. ciliaris is informative as this species is often found in areas with elevated levels of $\mathrm{P}$ in soils (Blackmore, Mentis \& Scholes 1990), which demonstrates why the MD is an important wet season range for herbivores. The Bothriochloa insculpta - Rhynchosia minima community is dominated by B. insculpta, which is adapted to seasonally flooded vertisols which form hard surfaces during winter (Cook \& Clem 2000). The well-developed root systems of these large perennial grasses (B. insculpta and C. ciliaris) also likely promote access to soil moisture from deeper water tables when surface water 
dries out during the dry season (Cook \& Clem 2000; Hamandawana 2011). The Setaria incrassata - Dichanthium annulatum community was dominated mainly by grass species such as $S$. incrassata, D. annulatum, P. coloratum, C. dactylon and D. milanjiana and occurred on seasonally flooded vertisols, with seasonal flooding maintaining this community as an open grassland with no trees (Cook \& Clem 2000). Species such as S. incrassata and D. annulatum are well-known dominants of seasonally flooded, heavy clay soils in southern Africa (Cook \& Clem 2000). This community type was found only in the north-eastern part of the MD and occurs in one of the most remote and inaccessible areas of northern Botswana, rarely ever accessed by people because there are no roads there and seasonal flooding of the heavy clay soils makes access impossible during the wet season. Our many sightings of roan antelope in this vegetation type while we were sampling suggest that it is regularly used by roan antelope, which is a species known to favour seasonally flooded grasslands and prefers areas with little disturbance by people.

\section{Conclusion}

This study demonstrated that large heterogeneity of plant communities driven by gradients in soil texture or fertility and wetness plays a key role in providing critical functional resource and habitat heterogeneity that allows (1) herbivores to adapt to seasonal variation in resources and (2) allows niche diversity to support a diverse guild of herbivores. Floodplains and seasonally flooded grasslands provide a reliable source of green forage during the dry season for herbivores, whereas the vast woodland mosaic of mopane and sandveld on alluvial soils and Kalahari sands provides cover, low predation risk and medium height, leafy grasses for rare herbivores all year round and for buffalo and elephant during the wet season. The fertile heavy clay soils of the MD provide additional functional resource heterogeneity in an ecosystem otherwise largely dominated by sandy soils, where elevated levels of minerals such as $\mathrm{Ca}$ and $\mathrm{P}$ in grasses on the MD enable pregnant and lactating females to meet their elevated requirements for these resources. Thus, the regional-scale separation of large wetland systems (a functional dry season habitat) from large woodland systems and the fertile clay soils of the MD (functional wet season habitats) is an underlying driver of both buffalo (wetlands to woodlands) and zebra (wetlands to paleolake systems) migrations in the SMLE (Bennitt et al. 2014; Naidoo et al. 2014; Sianga 2014).

Certain communities such as the Boscia albitrunca Dactyloctenium giganteum community provide a high density of trees with green leaves of acceptable quality during the dry season (e.g. B. albitrunca), which provide an important reserve resource for browsers at this time of the year (OwenSmith 2002). Thus, the heterogeneous mix of extensive sandveld, mopane and Baikiaea woodlands, open fertile grasslands and extensive wetland systems provides excellent functional habitat and resource heterogeneity in the ecosystem, which enables herbivores to adapt to variable resources needs and avoid predation. In addition, this heterogeneity creates niche diversity, which enables coexistence of a high diversity of large mammals (herbivores and carnivores), including one of the largest roan and sable antelope and eland populations in southern Africa. Thus, our results demonstrate that a key point of general significance for conservation science is that protected areas need to cover the main large-scale regional environmental gradients in a region (e.g. the full texture and wetness gradients in this study region) if they are to provide sufficient habitat heterogeneity needed to provide appropriate seasonal adaptive foraging options for wildlife and to support a diverse guild of herbivores and their associated predators. In addition, this vegetation classification and vegetation map will provide a critical database for wildlife habitat selection studies in the region and will be useful for environmental and conservation policy-makers in the assessment and monitoring of plant communities as well as for developing conservation strategies and management plans for the ecosystem.

\section{Acknowledgements}

The Ministry of Environment, Wildlife and Tourism and the Department of Wildlife and National Parks (Botswana) are highlighted for permitting us to conduct this research in northern Botswana (EWT 8/36/4 XXV [16]). The authors finally acknowledge Mrs. Sibonile Sibanda of Hatfield Consultants (Gaborone, Botswana) and Mrs. Marion Stelles and Dr Achim Roder (University of Trier, Germany) for their invaluable guidance with the remote sensing and vegetation mapping work. Great Plains Safaris (Selinda Reserve) and Okavango Wilderness Safaris (Botswana) are acknowledged for their logistic support. The authors acknowledge the Southern African Science Service Centre for Climate Change and the Adaptive Land Management (SASSCAL) for funding this research.

\section{Competing interests}

The authors declare that they have no financial or personal relationships that may have inappropriately influenced them in writing this article.

\section{Authors' contributions}

All authors directly participated in the planning, execution and analysis of this study.

\section{References}

Bartlam-Brooks, H.L.A., Bonyongo, M.C. \& Harris, S., 2013, 'How landscape scale changes affect ecological processes in conservation areas: External factors influence land use by zebra (Equus burchellii) in the Okavango Delta', Ecology and Evolution 3(9), 2795-2805. https://doi.org/10.1002/ece3.676

Bennitt, E., Bonyongo, M.C. \& Harris, S., 2014, 'Habitat selection by African buffalo (Syncerus caffer) in response to landscape-level fluctuations in water availability on two temporal scales', PLOS One 9(7), e101346. https://doi.org/10.1371/ journal.pone.0101346

Bennitt, E., Bonyongo, M.C. \& Harris, S., 2015, 'Behaviour-related scalar habitat use by Cape buffalo (Syncerus caffer)', PLoS One 10(12), e0145145. https://doi.org/ 10.1371/journal.pone.0145145 
Blackmore, A.C., Mentis, M.T. \& Scholes, R.J., 1990, 'The origin and extent of nutrientenriched patches within a nutrient-poor savanna in South Africa', Journal of Biogeography 17(4/5), 463-470. https://doi.org/10.2307/2845378

Coetzee, B., Van Der Meulen, F., Zwanziger, S., Gonsalves, P. \& Weisser, P., 1976 'A phytosociological classification of the Nylsvley Nature Reserve', Bothalia 12(1), 137-160. https://doi.org/10.4102/abc.v12i1.1388

Cook, B. \& Clem, R., 2000, 'Which grass for where?', Tropical Grasslands 34 156-161.

Dufrene, M. \& Legendre, P., 1997, 'Species assemblages and indicator species: The need for a flexible asymmetrical approach', Ecological Monographs 67(3), 345-366. https://doi.org/10.2307/2963459

Ellery, W.N., Ellery, K. \& Mccarthy, T.S., 1993, 'Plant distribution in islands of the Okavango Delta, Botswana: Determinants and feedback interactions', African
Journal of Ecology 31(2), 118-134. https://doi.org/10.1111/j.1365-2028.1993. Journal of

ENVI version 4.8, 2010, computer software, ITT Corporation, Boulder, CO.

Esri version 10.2, 2010, computer software, Environmental Systems Research Institute, Redlands, CA.

Fynn, R.W.S., Chase, M. \& Roder, A., 2014, 'Functional habitat heterogeneity and large herbivore seasonal habitat selection in northern Botswana', South African Journa of Wildlife Research 44(1), 1-15. https://doi.org/10.3957/056.044.0103

Fynn, R.W.S., Murray-Hudson, M., Dhliwayo, M. \& Scholte, P., 2015, 'African wetlands and their seasonal use by wild and domestic herbivores', Wetlands Ecology and Management 23(4), 559-581. https://doi.org/10.1007/s11273-015-9430-6

Gertenbach, W. \& Potgieter, A., 1978, 'A phytosociological classification of the Hlane Wildlife Sanctuary, Swaziland', Koedoe 21(1), 47-65. https://doi.org/10.4102/ koedoe.v21i1.960

Hamandawana, H., 2011, 'Methodology to detect long-term trends in groundwater by monitoring changes in vegetation distribution', International Journal of Remote Sensing 32(12), 3329-3343. https://doi.org/10.1080/01431161003747497

Harrington, R., Owen-Smith, N., Viljoen, P.C., Biggs, H.C., Mason, D.R. \& Funston, P. 1999, 'Establishing the causes of the roan antelope decline in the Kruger National Park, South Africa', Biological Conservation 90, 69-78. https://doi.org/10.1016/ S0006-3207(98)00120-7

Havemann, C.P., 2014, 'Population dynamics and foraging ecology of roan antelope in northern Botswana', MSc thesis, University of Pretoria, Pretoria, South Africa.

Heath, R. \& Heath, A., 2009, Field guide to the plants of Northern Botswana including the Okavango Delta, Royal Botanic Gardens, Richmond.

Hensman, M.C., Owen-Smith, N., Parrini, F. \& Bonyongo, C.M., 2014, 'Home range occupation and habitat use of sable antelope in the Okavango Delta region of northern Botswana', African Journal of Ecology 52(2), 237-245. https://doi. org/10.1111/aje.12111

Hobbs, N.T., Galvin, K.A., Stokes, C.J., Lackett, J.M., Ash, A.J., Boone, R.B. et al., 2008, 'Fragmentation of rangelands: Implications for humans, animals, and landscapes', Global Environmental Change-Human and Policy Dimensions 18, 776-785. https://doi.org/10.1016/j.gloenvcha.2008.07.011

Hopcraft, J.G.C., Olff, H. \& Sinclair, A., 2010, 'Herbivores, resources and risks: Alternating regulation along primary environmental gradients in savannas', Trends in Ecology \& Evolution 25(2), 119-128. https://doi.org/10.1016/j.tree. 2009.08.001

Hopcraft, J.G.C., Sinclair, A.R.E. \& Packer, C., 2005, 'Planning for success: Serenget lions seek prey accessibility rather than abundance', Journal of Animal Ecology 74 559-566. https://doi.org/10.1111/j.1365-2656.2005.00955.x

Joos-Vandewalle, M.E.J., 2000, 'Movements of migratory zebra and wildebeest in northern Botswana', PhD thesis, University of the Witwatersrand, Johannesburg South Africa.

MacFayden, S., Hui, C., Verberg, P.H. \& Van Teeffelen, A.J.A., 2016, 'Quantifying spatiotemporal drivers of environmental heterogeneity in Kruger National Park, South Africa', Landscape Ecology. Early View 31, 2013-2029.

Mccarthy, J., Gumbricht, T. \& Mccarthy, T.S., 2005, 'Ecoregion classification in the Okavango Delta, Botswana from multitemporal remote sensing', International
Journal of Remote Sensing 26(19), 4339-4357. https://doi.org/10.1080/ Journal of Remote

Mccune, B., Grace, J.B. \& Urban, D.L., 2002, Analysis of ecological communities, MjM Software Design, Gleneden Beach, OR.
Mendelsohn, J., Vanderpost, C., Ramberg, L., Murray-Hudson, M., Wolski, P. \& Mosepele K., 2010, Okavango delta: Floods of life, Raison, Windhoek.

Mills, M.G.L. \& Gorman, M., 1997, 'Factors affecting the density and distribution of wild dogs in the Kruger National Park', Conservation Biology 11, 1397-1406. https://doi.org/10.1046/j.1523-1739.1997.96252.x

Murray-Hudson, M., Combs, F., Wolski, P. \& Brown, M.T., 2011, 'A vegetation-based hierarchical classification for seasonally pulsed floodplains in the Okavango Delta, Botswana', African Journal of Aquatic Science 36, 223-234. https://doi.org/10.29 89/16085914.2011.636904

Murray-Hudson, M., Wolski, P., Murray-Hudson, F., Brown, M.T. \& Kashe, K., 2014 'Disaggregating hydroperiod: Components of the seasonal flood pulse as drivers of plant species distribution in floodplains of a tropical wetland', Wetlands 34 927-942. https://doi.org/10.1007/s13157-014-0554-x

Naidoo, R., Du Preez, P., Stuart-Hill, G., Beytell, P. \& Taylor, R., 2014, ‘Long-range migrations and dispersals of African buffalo (Syncerus caffer) in the KavangoZambezi transfrontier conservation area', African Journal of Ecology 52, 581-584. https://doi.org/10.1111/aje.12163

Owen-Smith, N., 2002, Adaptive herbivore ecology, Cambridge University Press, Cambridge.

Owen-Smith, N., 2004, 'Functional heterogeneity in resources within landscapes and herbivore population dynamics', Landscape Ecology 19(7), 761-771. https://doi. herbivore population dynamics',
org/10.1007/s10980-005-0247-2

Rettie, W.J. \& Messier, F., 2000, 'Hierarchical habitat selection by woodland caribou: Its relationship to limiting factors', Ecography 23(4), 466-478. https://doi.org/ 10.1111/j.1600-0587.2000.tb00303.x

Ringrose, S., 2006, REPORT: Results and struggles of the Elephant Habitat Mapping Project, University of Botswana, Botswana.

Ringrose, S., Vanderpost, C., Matheson, W., Wolski, P., Huntsman-Mapila, P., MurrayHudson, M. et al., 2007, 'Indicators of desiccation-driven change in the distal Okavango Delta, Botswana', Journal of Arid Environments 68(1), 88-112. https:// doi.org/10.1016/j.jaridenv.2006.03.030

Sianga, K., 2014, 'Habitat use by buffalo and zebra in relation to spatial and tempora variability of resources in the Savuti-Mababe-Linyanti ecosystem of northern Botswana', MPhil thesis, University of Botswana, Botswana.

Sianga, K., Fynn, R.W.S. \& Bonyongo, M.C., 2017a,'Seasonal habitat selection by African buffalo Syncerus caffer in the Savuti-Mababe-Linyanti ecosystem of northern Botswana', Koedoe 59(2), a1382. https://doi.org/10.4102/koedoe. v59i2.1382

Sianga, K., Van Telgen, M., Vrooman, J., Fynn, R.W.S. \& Van Langevelde, F. $2017 \mathrm{~b}$,'Spatial refuges buffer landscapes against homogenisation and degradation by large herbivore populations and facilitate vegetation heterogeneity', Koedoe by large herbivore populations and facilitate vegetation
59(2), a1434. https://doi.org/10.4102/koedoe.v59i2.1434

Taolo, C., 2003, 'Population ecology, seasonal movement and habitat use of the African buffalo (Syncerus caffer) in Chobe National Park, Botswana', PhD thesis, Norwegian University of Science and Technology, Trondheim, Norway.

Tedder, M.J., 2012, 'Dry woodland and savanna vegetation dynamics in the Eastern Okavango Delta, Botswana', PhD thesis, University of KwaZulu-Natal, Pietermaritzburg.

Tedder, M.J., Kirkman, K.P., Morris, C.D., Trollope, W.S.W. \& Bonyongo, M.C., 2013 'Classification and mapping of the composition and structure of dry woodland and savanna in the eastern Okavango Delta', Koedoe 55(1), 1-8. https://doi. $\operatorname{org} / 10.4102 /$ koedoe.v55i1.1100

Teter, K.L., 2007, 'Paleoenvironmental reconstruction of Paleolake Mababe, northwestern Botswana from sediment chemistry and biological productivity data', MSc thesis, Oklahoma State University, Stillwater, OK.

The plant list, Version 1.1. viewed 13 January 2017, from http://www.theplantlist.org Van Voorthuizen, E.G., 1976, 'The mopane tree', Botswana Notes and Records 8 223-230.

Witkowski, E. \& O'connor, T., 1996, 'Topo-edaphic, floristic and physiognomic gradients of woody plants in a semi-arid African savanna woodland', Vegetatio 124(1), 9-23. https://doi.org/10.1007/BF00045140

Wolski, P. \& Murray-Hudson, M., 2006, 'Flooding dynamics in a large low-gradient alluvial fan, the Okavango Delta, Botswana, from analysis and interpretation of 30 -year hydrometric record', Hydrology and Earth System Sciences Discussions 10(1), 127-137. https://doi.org/10.5194/hess-10-127-2006 


\section{Appendix 1}

TABLE 1-A1: Multiresponse permutation procedure pairwise comparisons between identified classes for plant communities in the Savuti-Mababe-Linyanti ecosystem (northern Botswana).

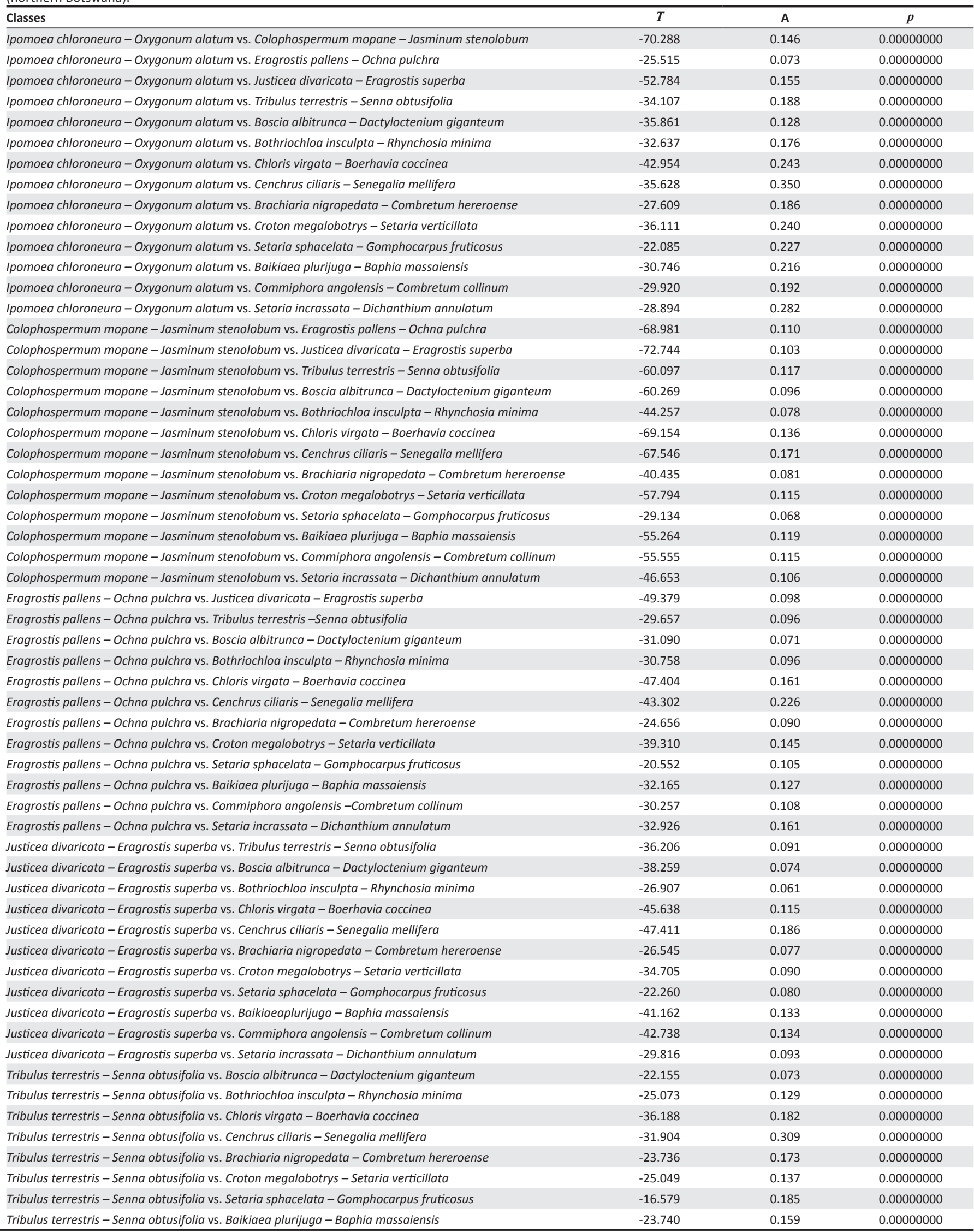


TABLE 1-A1 (Continues...): Multiresponse permutation procedure pairwise comparisons between identified classes for plant communities in the Savuti-Mababe-Linyanti ecosystem (northern Botswana).

\begin{tabular}{|c|c|c|c|}
\hline Classes & $T$ & A & $p$ \\
\hline Tribulus terrestris - Senna obtusifolia vs. Commiphora angolensis - Combretum collinum & -28.344 & 0.204 & 0.00000000 \\
\hline Tribulus terrestris - Senna obtusifolia vs. Setaria incrassata - Dichanthium annulatum & -24.258 & 0.240 & 0.00000000 \\
\hline Boscia albitrunca - Dactyloctenium giganteum vs. Bothriochloa insculpta - Rhynchosia minima & -24.395 & 0.079 & 0.00000000 \\
\hline Boscia albitrunca - Dactyloctenium giganteum vs. Chloris virgata-Boerhavia coccinea & -39.658 & 0.130 & 0.00000000 \\
\hline Boscia albitrunca-Dactyloctenium giganteum vs. Cenchrus ciliaris - Senegalia mellifera & -38.826 & 0.216 & 0.00000000 \\
\hline Boscia albitrunca-Dactyloctenium giganteum vs. Brachiaria nigropedata-Combretum hereroense & -25.765 & 0.108 & 0.00000000 \\
\hline Boscia albitrunca - Dactyloctenium giganteum vs. Croton megalobotrys - Setaria verticillata & -30.694 & 0.115 & 0.00000000 \\
\hline Boscia albitrunca - Dactyloctenium giganteum vs. Setaria sphacelata-Gomphocarpus fruticosus & -17.100 & 0.099 & 0.00000000 \\
\hline Boscia albitrunca-Dactyloctenium giganteum vs. Baikiaea plurijuga-Baphia massaiensis & -30.725 & 0.135 & 0.00000000 \\
\hline Boscia albitrunca-Dactyloctenium giganteum vs. Commiphora angolensis - Combretum collinum & -28.082 & 0.115 & 0.00000000 \\
\hline Boscia albitrunca - Dactyloctenium giganteum vs. Setaria incrassata - Dichanthium annulatum & -29.545 & 0.160 & 0.00000000 \\
\hline Bothriochloa insculpta - Rhynchosia minima vs. Chloris virgata-Boerhavia coccinea & -23.551 & 0.100 & 0.00000000 \\
\hline Bothriochloa insculpta - Rhynchosia minima vs. Cenchrus ciliaris - Senegalia mellifera & -24.442 & 0.200 & 0.00000000 \\
\hline Bothriochloa insculpta-Rhynchosia minima vs. Brachiaria nigropedata-Combretum hereroense & -19.987 & 0.140 & 0.00000000 \\
\hline Bothriochloa insculpta - Rhynchosia minima vs. Setaria sphacelata-Gomphocarpus fruticosus & -13.788 & 0.158 & 0.00000000 \\
\hline Bothriochloa insculpta - Rhynchosia minima vs. Baikiaea plurijuga-Baphia massaiensis & -23.962 & 0.179 & 0.00000000 \\
\hline Bothriochloa insculpta - Rhynchosia minima vs. Commiphora angolensis - Combretum collinum & -25.536 & 0.178 & 0.00000000 \\
\hline Bothriochloa insculpta - Rhynchosia minima vs. Setaria incrassata - Dichanthium annulatum & -19.200 & 0.178 & 0.00000000 \\
\hline Chloris virgata - Boerhavia coccinea vs. Cenchrus ciliaris - Senegalia mellifera & -35.426 & 0.287 & 0.00000000 \\
\hline Chloris virgata-Boerhavia coccinea vs. Brachiaria nigropedata-Combretum hereroense & -29.563 & 0.191 & 0.00000000 \\
\hline Chloris virgata - Boerhavia coccinea vs. Croton megalobotrys - Setaria verticillata & -34.587 & 0.187 & 0.00000000 \\
\hline Chloris virgata-Boerhavia coccinea vs. Setaria sphacelata-Gomphocarpus fruticosus & -20.598 & 0.171 & 0.00000000 \\
\hline Chloris virgata-Boerhavia coccinea vs. Baikiaea plurijuga-Baphia massaiensis & -33.380 & 0.234 & 0.00000000 \\
\hline Chloris virgata - Boerhavia coccinea vs. Commiphora angolensis - Combretum collinum & -34.826 & 0.235 & 0.00000000 \\
\hline Chloris virgata-Boerhavia coccinea vs. Setaria incrassata-Dichanthium annulatum & -28.163 & 0.228 & 0.00000000 \\
\hline Cenchrus ciliaris - Senegalia mellifera vs. Brachiaria nigropedata-Combretum hereroense & -24.087 & 0.347 & 0.00000000 \\
\hline Cenchrus ciliaris - Senegalia mellifera vs. Croton megalobotrys - Setaria verticillata & -29.356 & 0.320 & 0.00000000 \\
\hline Cenchrus ciliaris - Senegalia mellifera vs. Setaria sphacelata - Gomphocarpus fruticosus & -16.892 & 0.425 & 0.00000002 \\
\hline Cenchrus ciliaris - Senegalia mellifera vs. Setaria incrassata - Dichanthium annulatum & -22.269 & 0.433 & 0.00000000 \\
\hline Brachiaria nigropedata - Combretum hereroense vs. Croton megalobotrys - Setaria verticillata & -23.983 & 0.202 & 0.00000000 \\
\hline Brachiaria nigropedata-Combretum hereroense vs. Setaria sphacelata-Gomphocarpus fruticosus & -13.628 & 0.298 & 0.00000043 \\
\hline Brachiaria nigropedata-Combretum hereroense vs. Baikiaea plurijuga - Baphia massaiensis & -21.706 & 0.246 & 0.00000000 \\
\hline Brachiaria nigropedata - Combretum hereroense vs.Commiphora angolensis - Combretum collinum & -22.341 & 0.214 & 0.00000000 \\
\hline Brachiaria nigropedata - Combretum hereroense vs. Setaria incrassata - Dichanthium annulatum & -18.366 & 0.304 & 0.00000004 \\
\hline Croton megalobotrys - Setaria verticillata vs. Setaria sphacelata - Gomphocarpus fruticosus & -17.090 & 0.230 & 0.00000000 \\
\hline Croton megalobotrys - Setaria verticillata vs. Baikiaea plurijuga - Baphia massaiensis & -26.743 & 0.238 & 0.00000000 \\
\hline Croton megalobotrys - Setaria verticillata vs. Commiphora angolensis - Combretum collinum & -28.762 & 0.252 & 0.00000000 \\
\hline Croton megalobotrys - Setaria verticillata vs. Setaria incrassata - Dichanthium annulatum & -22.958 & 0.266 & 0.00000000 \\
\hline Setaria sphacelata-Gomphocarpus fruticosus vs. Baikiaea plurijuga-Baphia massaiensis & -15.172 & 0.313 & 0.00000003 \\
\hline Setaria sphacelata - Gomphocarpus fruticosus vs. Commiphora angolensis - Combretum collinum & -16.610 & 0.300 & 0.00000001 \\
\hline Setaria sphacelata-Gomphocarpus fruticosus vs. Setaria incrassata-Dichanthium annulatum & -11.836 & 0.457 & 0.00000431 \\
\hline Baikiaea plurijuga - Baphia massaiensis vs. Commiphora angolensis - Combretum collinum & -24.821 & 0.258 & 0.00000000 \\
\hline Baikiaea plurijuga - Baphia massaiensis vs. Setaria incrassata - Dichanthium annulatum & -20.584 & 0.339 & 0.00000000 \\
\hline Commiphora angolensis - Combretum collinum vs. Setaria incrassata - Dichanthium annulatum & -21.901 & 0.334 & 0.00000000 \\
\hline
\end{tabular}

$t$, test statistic; $A$, chance-corrected within group agreement; $p$, probability of a smaller or equal $\delta$ (not corrected for multiple comparisons). 


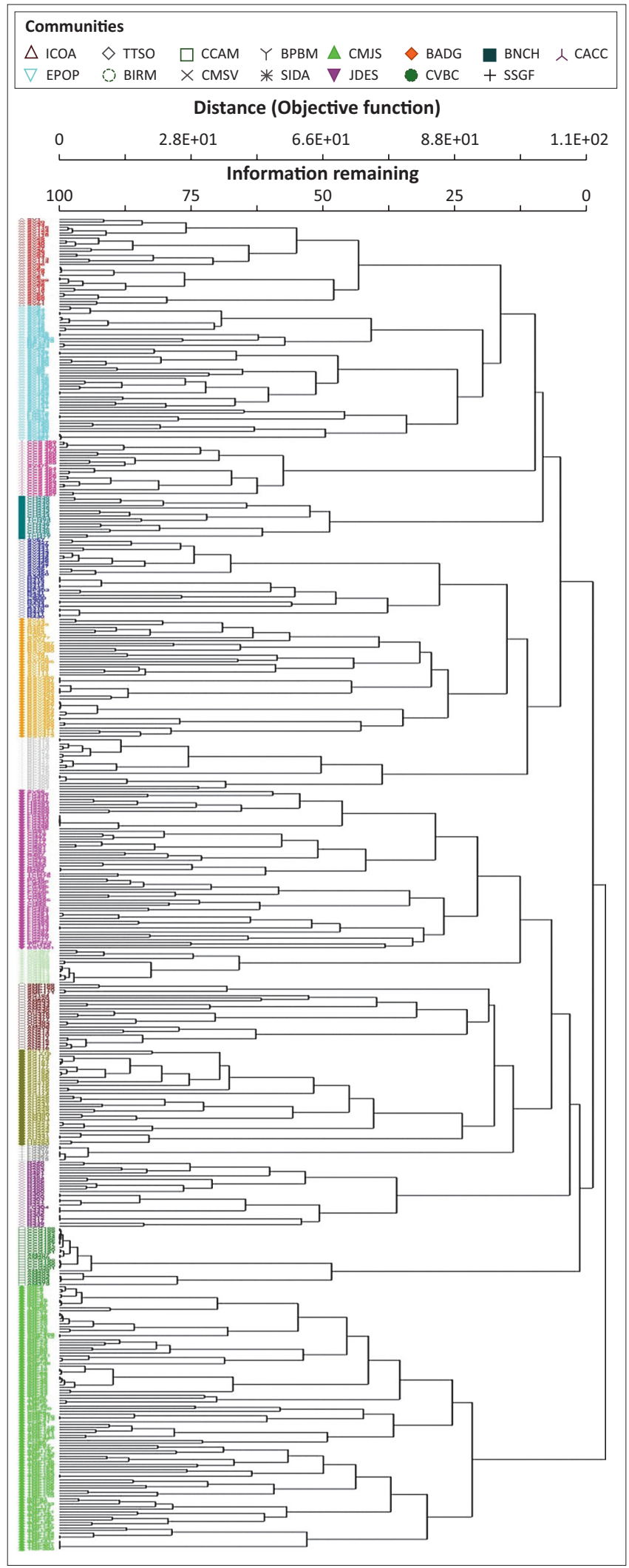

BADG, Boscia albitrunca - Dactyloctenium giganteum; BIRM, Bothriochloa insculpta Rhynchosia minima; BNCH, Brachiaria nigropedata - Combretum hereroense; BPBM,

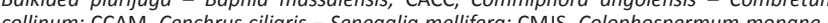
collinum, CCAM, Cenchrus ciliaris - Senegalia mellifera; CMJs, Colophospermum Jasminum stenolobum; CMSV, Croton megalobotrys - Setaria verticillata; CVBC, Chloris virgata - Boerhavia coccinea; EPOP, Eragrostis pallens - Ochna pulchra; ICOA, Ipomoea chloroneura - Oxygonum alatum; JDES, Justicea divaricata - Eragrostis superba; SIDA Setaria incrassata - Dichanthium annulatum; SSGF, Setaria sphacelata - Gomphocarpus fruticosus; TTSO, Tribulus terrestris - Senna obtusifolia.

FIGURE 1-A1: Cluster analysis showing the 15 plant communities identified in the Savuti-Mababe-Linyanti ecosystem, northern Botswana. 